\title{
Association between distress and displacement settings: a cross-sectional survey among displaced Yazidis in northern Iraq
}

Phuong N. Pham ${ }^{1,2,3^{*}+}$, Laila Fozouni ${ }^{1,2,4 \dagger}$, Abdulrazzaq al-Saiedi ${ }^{1}$, Kevin Coughlin ${ }^{1,2}$ and Patrick Vinck ${ }^{1,2,3}$

\begin{abstract}
Background: Globally 70.8 million people have been forcibly displaced from their homes and are at disproportionally high risk for trauma. At the time of this study, there was an estimated 1.6 million internally displaced persons (IDP) in Iraq, more than two-thirds of whom reside in private, urban settings. This study aims to understand the impact of post-displacement accommodation on mental well-being of the Yazidi minority group displaced in Iraq.

Methods: Multi-stage stratified sampling was used to randomly select IDPs in camp and out of camp settlements in northern Iraq. Standardized questionnaires evaluated factors including exposure to violence and self-reported distress symptoms (measured by Impact of Event Scale-Revised). A multi-variate linear model assessed the relationship between settlement setting and distress symptoms.

Results: One thousand two hundred fifty-six displaced Yazidi participants were included in the study: 63\% in camps and $37 \%$ out of camps. After controlling for exposure to violence, social cohesion, unemployment, and access to basic services, IDPs in camps were predicted to have a 19\% higher mean distress symptom score compared to those out of camps.

Conclusions: This study provides a framework to investigate post-displacement accommodation as a potential intervention to improve well-being for displaced populations. With a shift towards new models of emergency and long-term housing, it is important to understand the potential and limitations of more decentralized models, and identify effective methods to maintain access to basic services while improving living conditions for both displaced populations and their host communities.
\end{abstract}

Keywords: Refugees, Built environment, Housing, Mental health, Trauma

\footnotetext{
* Correspondence: ppham@hsph.harvard.edu

${ }^{\dagger *}$ Co-first authors: Pham and Fozouni contributed equally to this article

'Harvard Humanitarian Initiative, Harvard University, 14 Story Street,

Cambridge, MA 02138, USA

${ }^{2}$ Harvard T.H. Chan School of Public Health, 677 Huntington Ave, Boston, MA

02115, USA

Full list of author information is available at the end of the article
}

(c) The Author(s). 2021 Open Access This article is licensed under a Creative Commons Attribution 4.0 International License, which permits use, sharing, adaptation, distribution and reproduction in any medium or format, as long as you give appropriate credit to the original author(s) and the source, provide a link to the Creative Commons licence, and indicate if changes were made. The images or other third party material in this article are included in the article's Creative Commons licence, unless indicated otherwise in a credit line to the material. If material is not included in the article's Creative Commons licence and your intended use is not permitted by statutory regulation or exceeds the permitted use, you will need to obtain permission directly from the copyright holder. To view a copy of this licence, visit http://creativecommons.org/licenses/by/4.0/. The Creative Commons Public Domain Dedication waiver (http://creativecommons.org/publicdomain/zero/1.0/) applies to the data made available in this article, unless otherwise stated in a credit line to the data. 


\section{Background}

Worldwide, displaced populations are at a disproportionally high risk for trauma and mental illness such as posttraumatic stress disorder (PTSD), depression, and somatization before, during and after displacement [1-6]. The built environment (i.e. man-made structures in which people live and work) plays an important role in displaced populations' well-being [7-12]. Research has identified camp conditions and post-displacement accommodations as important predictors of mental health $[11,13]$. Exposure to violence and daily stressors, including those associated with the built environment and socioeconomic hardship, are associated with PTSD and poor mental health among these populations, suggesting that discontinuation of these stressors can be an important intervention to mitigate the consequences of trauma $[4,14,15]$. Separately, the relationship between cities, urban living and mental health has been well documented for the general population, but not for displaced populations [16-18]. As displaced populations increasingly seek shelter in urban areas and the international community shifts away from establishing traditional camps for displaced populations, there is a need to better understand the implication of temporary settlement choices on mental health and explore how the built environment specifically can be conceptualized as an intervention to improve mental health and long-term outcomes [11].

The purpose of this study is to compare mental health outcomes and distress symptoms among internally displaced persons (IDPs) living in camps versus out of formal camp settlements in northern Iraq. Understanding and addressing mental health issues among this group is important; poor mental health can cause a myriad of downstream effects, including negatively impacting views on reconciliation and non-violence as a means to end conflict $[19,20]$.

This study focused specifically on Yazidis, an ethnoreligious minority group from northwestern Iraq, which was victim to mass atrocities committed by the Islamic State (IS) [21]. On August 2014, IS attacked the city of Sinjar and its surrounding areas in Nineveh Governate where the Yazidi communities were primarily based. Although IS no longer occupies the Yazidi areas in the Nineveh Governorate (including Sinjar), about 230,000 Yazidis remain displaced in the Kurdistan region [22]. A study of Yazidi women and children, 16\% of whom had survived enslavement, found that over $80 \%$ met clinical criteria for DSM-5 PTSD diagnosis [23].

At the time of this study, there were an estimated 1.6 million IDPs in Iraq, many of whom were targeted by ISIL in 2013 for their identity, including Sunni and Shi'a Muslims, Shabak, Turkmen, and Yazidis [24, 25]. More than two-thirds of displaced people in Iraq reside out of camps; the majority of IDPs residing out of camps live in rented accommodations, and a smaller percentage live with host families or in informal settlements (e.g. unoccupied buildings) [26-28]. We hypothesized that while IDPs outside of formal camp settlements face several adverse factors [29], they also retain a higher level of control and quality of life, including social interactions, compared to camp-based IDPs, contributing to improved mental health.

\section{Methods}

\section{Survey sites and sample selection}

Participants for this study were selected among IDPs in out of camp (urban) and camp-based settlements in the Niveneh governorate and in the Erbil and Duhok governorates in the Kurdistan Region of Iraq (KRI). Multistage stratified sampling strategies were used for both population groups.. Sample size for the two population groups was determined using the sample size formulation for difference in proportions. We assumed a $90 \%$ confidence with a $\mathrm{Z}$ distribution, $80 \%$ power, and a difference of $20 \%$ and a design effect of 2 , for a total target of 150 interviews per group. This target was adjusted by $20 \%$ for anticipated non-response and rounded for logistical purposes and equal assignment to interviewers, for a target of 200 interviews. We anticipated multiple comparisons within each population groups based on gender and known ethnic diversity. The target sample size for IDP in camps was 1800 interviews. The target sample size for IDPs out of camp was 1200.

For IDPs in camps, 15 out of 31 camps for IDPs were randomly selected proportionate to population size using the latest data from the United Nations High Commissioner for Refugees (UNHCR). Within camps, interviewers were randomly assigned to blocks of similar sizes where they used a geographic sampling method to randomly select participants. Interviews could not be completed in two of the camps because the presence of IS family members posed a security risk for the interviewers. As a result, 1575 interviews were ultimately conducted with IDPs in camps $(87.5 \%$ of targeted 1800 interviews, within the $20 \%$ margin).

A similar multi-stage stratified sampling strategy was used to randomly select IDPs out of camps. Five out of 12 subdistricts were randomly selected proportionately to the out of camp population size based on the latest data from the International Organization for Migration (IOM) (mid-2018) available at the time of the survey. Within the subdistricts, 3 sites (neighborhoods) identified by IOM as hosting IDPs were randomly selected, proportionate to the IDP population size. In one subdistrict, four sites were selected due to the small population at each site. Once at the site, interviewers randomly selected a direction and approached every fifth household. If the household did not host IDPs, they were 
skipped. Because of the small number of IDPs present at each site, an additional 9 sites (neighborhoods) were randomly sampled, resulting in a final sample size of 1406 IDPs not living in camps (117.2\% of the target).

From the two sample of IDPs (in and out of camps), only those that indicated being part of the Yazidi ethnic religious group were included in this study. The rationale for the sub-sample was to increase homogeneity in the socio-cultural background and characteristics that have been shown to be associated with mental health. Among 1575 IDPs residing in camp, 794 were Yazidis (50.4\%), and 462 Yazidis were among the sampled 1406 IDPs living out of camps (32.9\%).

The study protocol was reviewed and approved by Partners Human Research Committee (PHRC, Protocol \#2018P001748)) and a local ad-hoc committee and local authorities in northern Iraq where the data were collected.

\section{Data collection instruments and scale}

Respondents were asked questions regarding exposures to violence, social cohesion, access to services, and household assets. Household assets were categorized as medium assets (bed, fridge, and washing machine) and extended assets (mobile phone, internet access, radio, computer, microwave, heater, car, and television) per the UNHCR Vulnerability Assessment [30].

The 22-item Impact of Event Scale-Revised (IES-R) based on a Likert scale of 0 (not at all) to 4 (in full) was used as a validated instrument to estimate subjective distress and calculate a distress score. Possible scores ranged from 0 to 88 , and a score of greater than 33 has been established to be have high diagnostic accuracy for PTSD [31, 32].

\section{Statistical analysis}

Statistical analyses were performed using Stata (v15, SE). Baseline demographics were presented as medians [interquartile ranges (IQR)] for continuous variables or percentages for categorical variables and compared by post-migration settlement location using Wilcoxon rank sum or chi-square test. Given low numbers of nonresponse, non-response answers were treated as missing values.

Linear regression was used to assess associations between distress scores and settlement location. Exposure to violence variables were converted into binary variables in regression to reflect any history of past exposure. Social cohesion variables were aggregated into a score (ranging from 1 to 29), with 1 indicating the least amount and 29 the highest amount of social cohesion. All variables associated with the outcome of interest with a $p$-value of $<0.2$ in univariable analysis or deemed relevant to post-displacement accommodation were evaluated for inclusion in the final model. Backwards stepwise regression was then performed to derive the final multivariable model which included variables associated with a $p$-value of $<0.05$ as well as variables forced in for known association with distress score.

\section{Results}

\section{General characteristics of respondents}

A total of 1256 participants were included in the study; $63 \%$ of sampled respondents were living in camps and $37 \%$ were living out of camps, all in urban settings, at the time of the survey (Fig. 1).

As shown in Table 1, the median (IQR) age of respondents was 30 (24-41), and $49 \%$ of the respondents were female; these did not differ by re-settlement location. The majority of both in camp (70\%) and out of camp (73\%) respondents were married at the time of the survey. In camp and out of camp respondents had similar rates of illiteracy (46 and 44\% respectively), education levels, and main occupations prior to the IS attack (Table 1). Employment differed between the two groups $(p=0.002)$ after the IS attack with respondents living inside camps having higher rates of unemployment $(29 \%$ versus 20\%) and lower rates of being self-employed (14\% versus 16\%). Income also differed between the two groups $(p=0.02)$, with respondents living in camps more likely to have incomes under 300,000 IQD per month (65\% versus $55 \%)$.

\section{Exposure to violence}

Complete data on exposure to 14 trauma events were assessed among respondents (Table 2).

Exposure to violence was highly prevalent among the respondents during ISIS control of their governorate. Seventy-eight percent of respondents had been exposed to a combat situation, and $69 \%$ had experienced starvation/lack of nutrition. Fifty-six percent of respondents had experienced forced evacuation, 30\% had been threatened with death, $23 \%$ had witnessed a killing or murder, and $16 \%$ had been tortured, and 15\% had witnessed torture. Smaller percentages of respondents had been imprisoned (8\%), had forced separation from family members (6\%), experienced beating and/or mutilation to body (5\%), developed disability as result of combat situation or landmine (4\%), witnessed rape/sexual abuse (3\%), been kidnapped/abducted for over a week (3\%), or experienced rape or other types of sexual abuse/humiliation (2\%).

Reported exposure to violence differed between Yazidi IDPs in camps and those out of camps. When looking at total past exposure, IDPs living in camps were more likely to have witnessed killing or a murder (OR 1.69, 95\% CI 1.27-2.25 $p<0.001$ ), to have witnessed beating or torture to head or body (OR 1.50, 95\% CI 1.07-2.09 


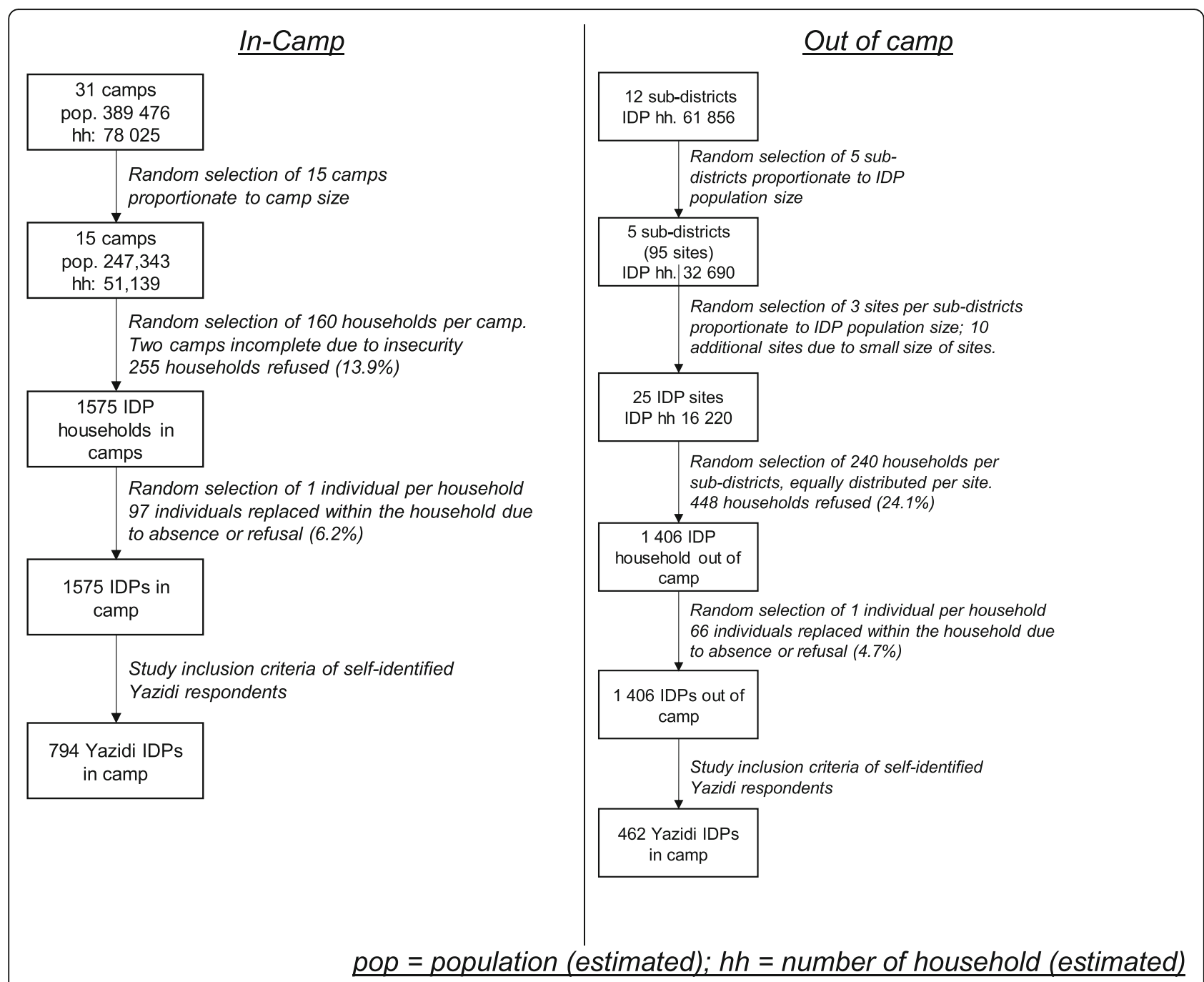

Fig. 1 Sampling and stratification strategies. pop = population (estimated); hh = number of household (estimated)

$\mathrm{p}=0.02$ ), to have experienced a combat situation (OR 1.52 , 95\% CI $1.16-2.00 \mathrm{p}=0.002)$, and to have been victims of torture (OR 1.61, 95\% CI 1.16-2.26 $p=0.004$ ). Rates of other exposures to violence were similar between the two groups.

\section{Sense of community and trust}

Perceptions about trust and community are shown as percentages in Table 3.

When asked about sense of safety in their current location, $94 \%$ of respondents reported that they felt safe in the location that they were residing, and $69 \%$ of them considered their current residence their home. Seventytwo percent of respondents responded that they trust the people in their current location "Quite a bit" or "Extremely." Overall, there were high rates of positive relationships with family (95\% "Good" or "Very Good"), with friends and neighbors (97\% "Good" or "Very
Good"), with the community in general (90\% "Good" or "Very Good"), with people from other ethnic groups (81\% "Good" or "Very Good") and people from other religious groups (84\% "Good" or "Very Good"). In an aggregated score looking at perception of relationships, ranging from 1 (lowest) to 29 (highest), the median score was 23 (IQR 22-27).

Perceptions of community and relationships differed between the two groups. Respondents residing out of camps were more likely to trust people in their current location "Quite a Bit" (47\% versus 38\%) but less likely to trust people "Extremely" (27\% versus $32 \%, p=0.01)$. Respondents residing out of camps were nearly 2 times more likely to feel safe in the location of their residence (OR 1.99, 95\% CI 1.08-3.67, $p=0.03$ ). Out of camp respondents were more likely to report "Very Good" relationships with people from any other ethnic group (31\% versus $26 \%, p=0.049)$ or 
Table 1 Characteristics of 1256 Yazidi internally displaced persons included in this study

\begin{tabular}{|c|c|c|c|c|c|}
\hline & & $\begin{array}{l}\text { All } \\
n= \\
1256\end{array}$ & $\begin{array}{l}\text { In Camp } \\
n=794 \\
(63 \%)\end{array}$ & $\begin{array}{l}\text { Out of Camp } \\
n=462 \\
(37 \%)\end{array}$ & $p$-value \\
\hline Age, years & & $30(24-41)$ & $30(24-40)$ & $31(24-42)$ & 0.26 \\
\hline Female & & $49 \%$ & $49 \%$ & $48 \%$ & 0.80 \\
\hline \multirow[t]{4}{*}{ Marital Status } & Married & $71 \%$ & $70 \%$ & $73 \%$ & 0.46 \\
\hline & Widowed & $2 \%$ & $3 \%$ & $2 \%$ & \\
\hline & Divorced & $0 \%$ & $1 \%$ & $0 \%$ & \\
\hline & Single or never married & $26 \%$ & $27 \%$ & $25 \%$ & \\
\hline Illiterate & & $45 \%$ & $46 \%$ & $44 \%$ & 0.35 \\
\hline \multirow[t]{6}{*}{ Education level } & None & $42 \%$ & $42 \%$ & $41 \%$ & 0.17 \\
\hline & Some primary & $15 \%$ & $16 \%$ & $14 \%$ & \\
\hline & Finished primary & $11 \%$ & $10 \%$ & $12 \%$ & \\
\hline & Intermediate & $19 \%$ & $16 \%$ & $16 \%$ & \\
\hline & High school or above & $13 \%$ & $11 \%$ & $17 \%$ & \\
\hline & Other & $0 \%$ & $0 \%$ & $0 \%$ & \\
\hline \multirow[t]{8}{*}{ Main occupation before ISIS attack } & Farming/Livestock & $13 \%$ & $14 \%$ & $12 \%$ & 0.65 \\
\hline & Government employee & $4 \%$ & $3 \%$ & $4 \%$ & \\
\hline & Self-employed & $19 \%$ & $20 \%$ & $18 \%$ & \\
\hline & Police/army & $4 \%$ & $5 \%$ & $4 \%$ & \\
\hline & Student & $22 \%$ & $22 \%$ & $22 \%$ & \\
\hline & Housewife & $30 \%$ & $29 \%$ & $31 \%$ & \\
\hline & Unemployed & $5 \%$ & $5 \%$ & $5 \%$ & \\
\hline & Other & $3 \%$ & $2 \%$ & $4 \%$ & \\
\hline \multirow[t]{8}{*}{ Employment after ISIS attack } & Farming/Livestock & $2 \%$ & $2 \%$ & $3 \%$ & 0.002 \\
\hline & Government employee & $4 \%$ & $4 \%$ & $4 \%$ & \\
\hline & Self-employed & $16 \%$ & $14 \%$ & $16 \%$ & \\
\hline & Police/army & $3 \%$ & $3 \%$ & $3 \%$ & \\
\hline & Student & $7 \%$ & $7 \%$ & $7 \%$ & \\
\hline & Housewife & $38 \%$ & $38 \%$ & $38 \%$ & \\
\hline & Unemployed & $26 \%$ & $29 \%$ & $20 \%$ & \\
\hline & Other & $4 \%$ & $3 \%$ & $7 \%$ & \\
\hline \multirow[t]{4}{*}{ Current income } & $<300,000$ IQD per month & $61 \%$ & $65 \%$ & $55 \%$ & 0.02 \\
\hline & Between $300,000-600,000$ IQD per month & $20 \%$ & $18 \%$ & $25 \%$ & \\
\hline & $>600,000$ IQD per month & $8 \%$ & $7 \%$ & $9 \%$ & \\
\hline & No response/Other & $11 \%$ & $11 \%$ & $11 \%$ & \\
\hline
\end{tabular}

${ }^{*}$ Median (IQR)

"Very Good" relationship with people from any other religious group $(31 \%$ versus $27 \%, p=0.04)$. In an aggregated score of social relationships, there was no difference between those residing in camps versus out of camps $(p=0.79)$.

\section{Quality of life and access to services}

Perceptions regarding access to basic services varied widely depending on the service or commodity. Fiftyone percent of respondents reported "Good" or "Very good" access to water, $65 \%$ reported "Average" or above access to food, $57 \%$ reported "Average" or above access to education if needed, and 57\% reported "Average" or above housing quality. However, respondents were less satisfied regarding access to healthcare, ability to find employment, and access to administrative services, with 50,88 , and $68 \%$ respectively of respondents reporting "Bad" or "Very bad" access. The median number of medium assets was 3 (out of 3), and the median number of extended assets was 4 (out of 8 ). 
Table 2 Comparison of exposure to violence for IDPs living in camp and out of camp

\begin{tabular}{|c|c|c|c|c|c|}
\hline & & $\begin{array}{l}\text { All } \\
N= \\
1256\end{array}$ & $\begin{array}{l}\text { In Camp } \\
n=794 \\
(63 \%)\end{array}$ & $\begin{array}{l}\text { Out of Camp } \\
n=462 \\
(37 \%)\end{array}$ & $p$-value \\
\hline \multirow[t]{2}{*}{ Witness killing or murder } & Exposed & $23 \%$ & $27 \%$ & $18 \%$ & $<0.001$ \\
\hline & No response & $0 \%$ & $0 \%$ & $0 \%$ & \\
\hline \multirow[t]{2}{*}{ Witness beating or torture to head or body } & Exposed & $15 \%$ & $12 \%$ & $17 \%$ & 0.017 \\
\hline & No response & $0 \%$ & $0 \%$ & $0 \%$ & \\
\hline \multirow[t]{2}{*}{ Witnessed rape/sexual abuse } & Exposed & $3 \%$ & $3 \%$ & $3 \%$ & 0.64 \\
\hline & No response & $0.1 \%$ & $0.1 \%$ & $0 \%$ & \\
\hline \multirow[t]{2}{*}{ Were threatened with death } & Exposed & $30 \%$ & $31 \%$ & $27 \%$ & 0.21 \\
\hline & No response & $0 \%$ & $0 \%$ & $0 \%$ & \\
\hline \multirow[t]{2}{*}{ Were starved/lack of nutrition } & Exposed & $69 \%$ & $70 \%$ & $68 \%$ & 0.33 \\
\hline & No response & $0 \%$ & $0 \%$ & $0 \%$ & \\
\hline \multirow[t]{2}{*}{ Combat Situation } & Exposed & $78 \%$ & $81 \%$ & $73 \%$ & 0.002 \\
\hline & No response & $0 \%$ & $0 \%$ & $0 \%$ & \\
\hline \multirow[t]{2}{*}{ Forced Evacuation } & Exposed & $56 \%$ & $57 \%$ & $54 \%$ & 0.40 \\
\hline & No response & $0 \%$ & $0 \%$ & $0 \%$ & \\
\hline \multirow[t]{2}{*}{ Beating and/or mutilation to the body } & Exposed & $5 \%$ & $5 \%$ & $4 \%$ & 0.23 \\
\hline & No response & $0 \%$ & $0 \%$ & $0 \%$ & \\
\hline \multirow[t]{2}{*}{ Rape or other types of sexual abuse or humiliation } & Exposed & $2 \%$ & $3 \%$ & $2 \%$ & 0.52 \\
\hline & No response & $0 \%$ & $0 \%$ & $0 \%$ & \\
\hline \multirow[t]{2}{*}{ Disability as result of combat situation or landmine } & Exposed & $4 \%$ & $4 \%$ & $3 \%$ & 0.22 \\
\hline & No response & $0 \%$ & $0 \%$ & $0 \%$ & \\
\hline \multirow[t]{2}{*}{ Torture } & Exposed & $16 \%$ & $18 \%$ & $12 \%$ & 0.004 \\
\hline & No response & $0 \%$ & $0 \%$ & $0 \%$ & \\
\hline \multirow[t]{2}{*}{ Imprisonment } & Exposed & $8 \%$ & $8 \%$ & $6 \%$ & 0.16 \\
\hline & No response & $0 \%$ & $0 \%$ & $0 \%$ & \\
\hline \multirow[t]{2}{*}{ Being kidnapped/abducted for over a week } & Exposed & $3 \%$ & $3 \%$ & $3 \%$ & 0.69 \\
\hline & No response & $0 \%$ & $0 \%$ & $0 \%$ & \\
\hline \multirow[t]{2}{*}{ Other forced separation from family members } & Exposed & $6 \%$ & $6 \%$ & $5 \%$ & 0.52 \\
\hline & No response & $0 \%$ & $0 \%$ & $0 \%$ & \\
\hline
\end{tabular}

The distribution of responses also differed significantly by group, with more people living out of camps describing their housing as "Very bad" compared to those in camps ( $18 \%$ versus $12 \%, p=0.02)$. More respondents living out of camps also reported having "Very bad" access to food (14\% versus $5 \%, p<0.001)$, access to healthcare $(19 \%$ versus $11 \%, p=$ $0.001)$, and access to education ( $16 \%$ versus $10 \%, p=0.02)$. Both groups reported high rates of access to water $(p=0.61)$, and poor ability to find work/employment $(p=0.17)$. There was no difference in number of medium assets $(p=0.07)$ or extended assets $(p=.26)$ between the groups.

\section{Associations between accommodation and symptoms of distress}

Respondents overall reported high levels of distress symptoms. The median (IQR) distress score, on a scale of $0-88$, was 45 (28-57) among all respondents. Sixtynine percent of respondents had a score greater than or equal to 33. Among IDPs living in camps, their median (IQR) distress score was 48 (31-60), and among those living out of camps median (IQR) distress score was 40 (24-53). Seventy-three percent of IDPs in camps and $64 \%$ of those out of camps had scores greater than or equal to 33 (OR 1.50, 95\% CI 1.17-1.91 $p=0.001$ ).

In univariable linear regression, residing in a camp was associated with an average of a 7.7 point (19\%) increase in distress score from a predicted mean distress score of 38.75 (95\% CI 5.49-9.91 $p<0.001$ ); a complete list of results from univariable regression can be found in Table 4.

After conducting backwards stepwise regression with all variables that were associated with distress score with 
Table 3 Comparison of social cohesion measures between IDPs in camps versus out of camps

\begin{tabular}{|c|c|c|c|c|c|}
\hline & & $\begin{array}{l}\text { All } \\
n= \\
1256\end{array}$ & $\begin{array}{l}\text { In Camp } \\
n=794 \\
(63 \%)\end{array}$ & $\begin{array}{l}\text { Out of Camp } \\
n=462 \\
(37 \%)\end{array}$ & $p$-value \\
\hline \multirow[t]{6}{*}{ Relationship with family } & Very Bad & $<1 \%$ & $<1 \%$ & $<1 \%$ & 0.50 \\
\hline & Bad & $1 \%$ & $1 \%$ & $1 \%$ & \\
\hline & Average & $3 \%$ & $3 \%$ & $3 \%$ & \\
\hline & Good & $39 \%$ & $37 \%$ & $42 \%$ & \\
\hline & Very Good & $56 \%$ & $58 \%$ & $53 \%$ & \\
\hline & No Response & $0 \%$ & $0 \%$ & $0 \%$ & \\
\hline \multirow[t]{6}{*}{ Relationship with friends and neighbors } & Very Bad & $<1 \%$ & $<1 \%$ & $0 \%$ & 0.08 \\
\hline & Bad & $<1 \%$ & $<1 \%$ & $<1 \%$ & \\
\hline & Average & $2 \%$ & $2 \%$ & $2 \%$ & \\
\hline & Good & $47 \%$ & $45 \%$ & $50 \%$ & \\
\hline & Very Good & $50 \%$ & $52 \%$ & $46 \%$ & \\
\hline & No Response & $<1 \%$ & $0 \%$ & $<1 \%$ & \\
\hline \multirow[t]{6}{*}{ Relationship with community } & Very Bad & $<1 \%$ & $<1 \%$ & $<1 \%$ & 0.77 \\
\hline & Bad & $1 \%$ & $1 \%$ & $2 \%$ & \\
\hline & Average & $9 \%$ & $9 \%$ & $7 \%$ & \\
\hline & Good & $54 \%$ & $53 \%$ & $54 \%$ & \\
\hline & Very Good & $36 \%$ & $36 \%$ & $37 \%$ & \\
\hline & No Response & $0 \%$ & $0 \%$ & $0 \%$ & \\
\hline \multirow[t]{6}{*}{ Relationship with people from other ethnic groups } & Very Bad & $1 \%$ & $1 \%$ & $2 \%$ & 0.03 \\
\hline & Bad & $5 \%$ & $5 \%$ & $6 \%$ & \\
\hline & Average & $12 \%$ & $14 \%$ & $8 \%$ & \\
\hline & Good & $53 \%$ & $54 \%$ & $53 \%$ & \\
\hline & Very Good & $28 \%$ & $26 \%$ & $31 \%$ & \\
\hline & No Response & $<1 \%$ & $<1 \%$ & $<1 \%$ & \\
\hline \multirow[t]{6}{*}{ Relationship with people from other religious groups } & Very Bad & $<1 \%$ & $<1 \%$ & $<1 \%$ & 0.02 \\
\hline & Bad & $5 \%$ & $5 \%$ & $5 \%$ & \\
\hline & Average & $10 \%$ & $12 \%$ & $6 \%$ & \\
\hline & Good & $55 \%$ & $55 \%$ & $56 \%$ & \\
\hline & Very Good & $29 \%$ & $27 \%$ & $32 \%$ & \\
\hline & No Response & $<1 \%$ & $<1 \%$ & $<1 \%$ & \\
\hline \multirow[t]{6}{*}{ Your relationship with people from your ethnic group } & Very Bad & $0 \%$ & $0 \%$ & $0 \%$ & 0.65 \\
\hline & Bad & $<1 \%$ & $<1 \%$ & $<1 \%$ & \\
\hline & Average & $4 \%$ & $5 \%$ & $4 \%$ & \\
\hline & Good & $56 \%$ & $55 \%$ & $58 \%$ & \\
\hline & Very Good & $39 \%$ & $40 \%$ & $38 \%$ & \\
\hline & No Response & $0 \%$ & $0 \%$ & $0 \%$ & \\
\hline \multirow[t]{5}{*}{ Your relationship with people from your religious group } & Very Bad & $<1 \%$ & $<1 \%$ & $0 \%$ & 0.30 \\
\hline & Bad & $<1 \%$ & $<1 \%$ & $<1 \%$ & \\
\hline & Average & $4 \%$ & $4 \%$ & $3 \%$ & \\
\hline & Good & $53 \%$ & $51 \%$ & $57 \%$ & \\
\hline & Very Good & $42 \%$ & $44 \%$ & $39 \%$ & \\
\hline
\end{tabular}


Table 3 Comparison of social cohesion measures between IDPs in camps versus out of camps (Continued)

\begin{tabular}{|c|c|c|c|c|c|}
\hline & & $\begin{array}{l}\text { All } \\
n= \\
1256\end{array}$ & $\begin{array}{l}\text { In Camp } \\
n=794 \\
(63 \%)\end{array}$ & $\begin{array}{l}\text { Out of Camp } \\
n=462 \\
(37 \%)\end{array}$ & $p$-value \\
\hline & No Response & $<1 \%$ & $<1 \%$ & $0 \%$ & \\
\hline \multirow[t]{6}{*}{ How much do you trust the people in your current location } & Not at all & $3 \%$ & $3 \%$ & $2 \%$ & 0.01 \\
\hline & A little bit & $6 \%$ & $6 \%$ & $7 \%$ & \\
\hline & Moderately & $19 \%$ & $21 \%$ & $16 \%$ & \\
\hline & Quite a bit & $42 \%$ & $38 \%$ & $47 \%$ & \\
\hline & Extremely & $30 \%$ & $32 \%$ & $27 \%$ & \\
\hline & Don't Know & $<1 \%$ & $<1 \%$ & $0 \%$ & \\
\hline \multirow[t]{2}{*}{ Feel safe where you are staying now } & Yes & $94 \%$ & $93 \%$ & $97 \%$ & 0.01 \\
\hline & Missing & $1 \%$ & $2 \%$ & $<1 \%$ & \\
\hline \multirow[t]{2}{*}{ In place you consider home } & Yes & $69 \%$ & $68 \%$ & $72 \%$ & 0.10 \\
\hline & Missing & $1 \%$ & $2 \%$ & $<1 \%$ & \\
\hline
\end{tabular}

a $p<0.2$, staying in a camp remained significantly associated with an increased in distress score on average of 7.2 points $(p<0.001)$, after adjusting for witnessing beating or torture, experiencing starvation/lack of nutrition, forced evacuation, disability as result of combat situation or landmine, torture, other forced separation from family members, quality of relationship with people from any other religious group, amount of trust in people in current living situation, feeling of safety in current living situation, access to food, access to healthcare, access to education, and current unemployment.

\section{Discussion}

Our study found a high prevalence of distress symptoms among Yazidi IDPs living in northern Iraq, with 69\% of respondents meeting a distress symptom threshold that is highly predictive of PTSD. We also found that postdisplacement settlement setting (in camp compared to out of camp) was significantly associated with higher distress symptom scores, with IDPs in camps predicted to have a $19 \%$ higher mean score compared to IDPs out of camps. Even though IDPs in camps had higher rates of exposure to violence, this difference in mean distress symptom scores remained significant even after controlling for exposure to violence, social cohesion, unemployment, and access to services.

Moreover, despite IDPs out of camps having a lower prevalence of distress symptoms, they reported worse access to many important services, including access to food, healthcare, and education. Our findings are consistent with a survey conducted in 2017 as part of the Mixed Migration Platform, which found that IDPs living in private accommodations had a more negative perception of access to services compared to their counterparts living in camps [29]. Difficulties in accessing basic services and a higher rate of respondents reporting being very dissatisfied with their housing reflect the challenges of the decentralized nature of safety net services for displaced persons in out of camp settings.

These findings raise several important questions. First, the association between lower distress scores and out of camp accommodation, even after controlling for exposure to violence, may suggest that post-displacement accommodation could be viewed as an intervention in itself to reduce the severity of post-trauma sequelae. While there is a growing body of research demonstrating the importance of the built environment and physical space in impacting well-being, this is still poorly studied among displaced populations [33, 34]. Our research lays the necessary foundation for investigating this question further. Second, we observed this association despite IDPs reporting poorer access to basic services and greater dissatisfaction with their housing in out of camp settings. This highlights the ongoing conflict between prioritizing access to basic services in a centralized setting such as a camp, while upholding the dignity, autonomy, resiliency, and privacy of displaced persons. It also may suggest the relative importance of factors related to self-efficacy, such as independence and dignity, on mental health and alleviating the sequelae of trauma. Finally, our findings highlight the challenge of reduced visibility for IDPs residing in non-camp settings and how it can impede their ability to receive assistance and services. In fact, the Internal Displacement Monitoring Centre (IDMC) reported that IDPs in gathered settings, such as camps, were twice as likely to receive assistance and protection from national authorities and humanitarian actors compared to those in dispersed settings [28, 35]. Exploring creative development solutions where support can be provided to IDPs who are not in formal camp settings without overburdening host communities will be a challenge, but could be effective in addressing any 
Table 4 Logistic regression

\begin{tabular}{|c|c|c|}
\hline & $\begin{array}{l}\text { Univariable Coefficient } \\
P \text {-value }\end{array}$ & $\begin{array}{l}\text { Multivariable } \\
\text { Coefficient }\end{array}$ \\
\hline Staying in camps & $-7.70<0.001$ & $-7.15<0.001$ \\
\hline \multicolumn{3}{|l|}{ Exposure to Violence } \\
\hline \multirow[t]{2}{*}{ Witness killing or murder } & 4.77 & \\
\hline & $<0.001$ & \\
\hline \multirow{2}{*}{$\begin{array}{l}\text { Witness beating or } \\
\text { torture to head or body }\end{array}$} & 6.90 & 3.70 .01 \\
\hline & $<0.001$ & \\
\hline \multirow{2}{*}{$\begin{array}{l}\text { Witnessed rape/sexual } \\
\text { abuse }\end{array}$} & 13.97 & \\
\hline & $<0.001$ & \\
\hline \multirow{2}{*}{$\begin{array}{l}\text { Were threatened with } \\
\text { death }\end{array}$} & 4.15 & \\
\hline & 0.001 & \\
\hline \multirow{2}{*}{$\begin{array}{l}\text { Were starved/lack of } \\
\text { nutrition }\end{array}$} & 8.76 & $7.73<0.001$ \\
\hline & $<0.001$ & \\
\hline \multirow[t]{2}{*}{ Combat Situation } & 2.57 & \\
\hline & 0.05 & \\
\hline \multirow[t]{2}{*}{ Forced Evacuation } & 4.60 & -2.37 \\
\hline & $<0.001$ & 0.047 \\
\hline \multirow{2}{*}{$\begin{array}{l}\text { Beating and/or mutilation } \\
\text { to the body }\end{array}$} & 8.70 & \\
\hline & 0.001 & \\
\hline \multirow{2}{*}{$\begin{array}{l}\text { Rape or other types of } \\
\text { sexual abuse or } \\
\text { humiliation }\end{array}$} & 10.38 & \\
\hline & 0.005 & \\
\hline \multirow{2}{*}{$\begin{array}{l}\text { Disability as result of } \\
\text { combat situation or } \\
\text { landmine }\end{array}$} & 11.12 & 7.25 \\
\hline & $<0.001$ & 0.008 \\
\hline \multirow[t]{2}{*}{ Torture } & 8.05 & 3.94 \\
\hline & $<0.001$ & 0.009 \\
\hline \multirow[t]{2}{*}{ Imprisonment } & 4.97 & \\
\hline & 0.01 & \\
\hline \multirow{2}{*}{$\begin{array}{l}\text { Being kidnapped/ } \\
\text { abducted for over a week }\end{array}$} & 16.38 & \\
\hline & $<0.001$ & \\
\hline \multirow{2}{*}{$\begin{array}{l}\text { Other forced separation } \\
\text { from family members }\end{array}$} & 14.17 & 7.75 \\
\hline & $<0.001$ & 0.001 \\
\hline \multicolumn{3}{|l|}{ Social Cohesion } \\
\hline \multirow{2}{*}{$\begin{array}{l}\text { Relationship with people } \\
\text { from any other ethnic } \\
\text { group }\end{array}$} & 1.74 & \\
\hline & 0.008 & \\
\hline \multirow{2}{*}{$\begin{array}{l}\text { Relationship with people } \\
\text { from any other religious } \\
\text { group }\end{array}$} & 2.74 & 3.40 \\
\hline & $<0.001$ & $<0.001$ \\
\hline \multirow{2}{*}{$\begin{array}{l}\text { Amount of trust in people } \\
\text { in current living situation }\end{array}$} & 1.33 & 1.35 \\
\hline & 0.017 & 0.017 \\
\hline \multirow{2}{*}{$\begin{array}{l}\text { Feeling of safety in } \\
\text { current living situation }\end{array}$} & -7.89 & -6.44 \\
\hline & 0.002 & 0.009 \\
\hline \multirow[t]{2}{*}{ Housing } & -1.23 & \\
\hline & 0.11 & \\
\hline
\end{tabular}

Table 4 Logistic regression (Continued)

\begin{tabular}{lll}
\hline & $\begin{array}{l}\text { Univariable Coefficient } \\
\boldsymbol{P} \text {-value }\end{array}$ & $\begin{array}{l}\text { Multivariable } \\
\text { Coefficient }\end{array}$ \\
\hline Access to food & 1.76 & 2.80 \\
& 0.001 & $<0.001$ \\
Access to healthcare & -1.65 & -1.82 \\
& 0.001 & 0.001 \\
Ability to find work/ & -1.46 & \\
employment & 0.04 & -1.48 \\
Access to education if & -1.06 & 0.002 \\
needed & 0.04 & \\
Access to administrative & 0.71 & \\
services & 0.17 & 3.82 \\
Current Unemployment & 2.26 & 0.002 \\
& 0.07 & \\
Current Income & 0.01 & \\
\end{tabular}

pre-existing structural issues faced by host communities. Such solutions could consequently facilitate and strengthen a greater link between humanitarian actors and vulnerable populations while also promoting development for the host communities.

Our findings also highlight an important issue within an ongoing discussion around collective trauma. Many have argued that traditional Western psychological models are inadequate in the international context, and instead argue for more trans-cultural and post-modern approaches to psychological care [36]. Western models have also been critiqued for their internalized problem discourse, putting the burden of trauma on the individual and absolving society from its collective responsibility. Such an internalized problem discourse fails to acknowledge the ways in which interventions aimed at improving the socioeconomic and living conditions may be a strategy for improving mental health. Our research provides an important groundwork for thinking about such strategies.

Our study has some limitations. First, while we did not find any demographic differences among Yazidi IDPs resettled in camps versus out of camps, we do not know whether the location of post-displacement resettlement is impacted by where they were resided within Nineveh governorate pre-displacement as we did not ascertain this information. In addition, we lacked information regarding the quality of housing, such as number of individuals sharing a unit and size of unit. Furthermore, though we had a holistic survey looking at exposure to violence, it is possible that we missed exposures or did not adequately assess severity of exposure, which could have differed by post-displacement accommodation. 
Furthermore, we did not have information regarding time from exposure to violence, which could have impacted distress scores and potentially differed between IDPs settled in camp versus out of camp.

Despite these limitations, our study lays important groundwork to begin investigating alternatives to camplike settlements for displaced populations to improve their well-being and positive long-term outcomes. As the humanitarian community begins to shift towards new models of emergency and long-term housing, it will also be important to understand the potential and limitations of more decentralized models, and identify effective methods to maintain access to basic services while improving conditions for both displaced populations and host communities.

\section{Abbreviations}

IDPS: Internally displaced persons; IES-R: Impact of Event Scale-Revised; IOM: International Organization for Migration; IQR: Interquartile ranges; IS: Islamic State; KRI: Kurdistan Region of Iraq; PTSD: Post-traumatic stress disorder; UNHCR: United Nations High Commissioner for Refugees

\section{Acknowledgements}

Not applicable.

\section{Authors' contributions}

PP and PV and AA designed the study and obtained funding; PV, AA, and KC obtained the data, LF analyzed the data with PP and PV's guidance; LF, PP, and PV wrote initial draft. All authors contributed to data interpretation and edited the manuscript. The authors read and approved the final manuscript.

\section{Funding}

The study was funded by the Netherlands Ministry of Foreign Affairs, Stabilization and Humanitarian Aid Department. The funder had no role in study design, in the collection, analysis, and interpretation of data, and in the writing of the report and the decision to submit for publication.

\section{Availability of data and materials}

The data that support the findings of this study are available from Phuong Pham but restrictions apply to the availability of these data, which were used under license for the current study, and so are not publicly available. Data are however available from the authors upon reasonable request and with permission of Phuong Pham, ppham@hsph.harvard.edu.

\section{Declarations}

\section{Ethics approval and consent to participate}

The study protocol was reviewed and approved by Partners Human Research Committee (PHRC, Protocol \#2018P001748)) and a local ad-hoc committee and local authorities in northern Iraq where the data were collected. All methods were carried out in accordance with relevant guidelines and regulations. All experimental protocols were approved by Partners Human Research Committee (PHRC, Protocol \#2018P001748)) and a local adhoc committee and local authorities in northern Iraq where the data were collected. Informed consent was obtained from all subjects.

\section{Consent for publication}

Not applicable.

\section{Competing interests}

The authors declare that they have no competing interests.

\section{Author details}

${ }^{1}$ Harvard Humanitarian Initiative, Harvard University, 14 Story Street, Cambridge, MA 02138, USA. ${ }^{2}$ Harvard T.H. Chan School of Public Health, 677 Huntington Ave, Boston, MA 02115, USA. ${ }^{3}$ Brigham and Women's Hospital,

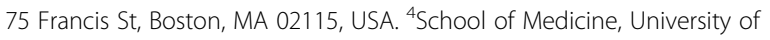
California, San Francisco, 505 Parnassus Ave, San Francisco, CA 94143, USA.

Received: 25 January 2021 Accepted: 26 March 2021

Published online: 08 April 2021

\section{References}

1. Kirmayer L, Narasiah L, Munoz M, Rashid M, Ryder AG, Guzder J, et al. Common mental health problems in immigrants and refugees: general approach in primary care. CMAJ. 2011;183(12):E959-67. https://doi.org/10.1 503/cmaj.090292.

2. Roberts B, Damundu EY, Lomoro O, Sondorp E. Post-conflict mental health needs: a cross-sectional survey of trauma, depression and associated factors in juba, Southern Sudan. BMC Psychiatr. 2009;9(1):7. https://doi.org/10.11 86/1471-244X-9-7.

3. Thomas SL, Thomas SD. Displacement and health. Br Med Bull. 2004;69(1): 115-27. https://doi.org/10.1093/bmb/ldh009.

4. Husain F, Anderson M, Lopes Cardozo B, Becknell K, Blanton C, Araki D, et al. Prevalence of war-related mental health conditions and association with displacement status in postwar Jaffna District, Sri Lanka. JAMA. 2011;306(5): 522-31. https://doi.org/10.1001/jama.2011.1052.

5. Thapa SB, Hauff E. Psychological distress among displaced persons during an armed conflict in Nepal. Soc Psychiatry Psychiatr Epidemiol. 2005;40(8): 672-9. https://doi.org/10.1007/s00127-005-0943-9.

6. Fazel $M$, Wheeler J, Danesh J. Prevalence of serious mental disorder in 7000 refugees resettled in western countries: a systematic review. Lancet. 2005: 365(9467):1309-14. https://doi.org/10.1016/S0140-6736(05)61027-6.

7. Murray KE, Davidson GR, Schweitzer RD. Review of refugee mental health interventions following resettlement: best practices and recommendations. Am J Orthop. 2010;80(4):576-85.

8. El-Bialy R, Mulay S. Two sides of the same coin: factors that support and challenge the wellbeing of refugees resettled in a small urban center. Health Place. 2015;35:52-9. https://doi.org/10.1016/j.healthplace.2015.06.009.

9. Beiser M. Resettling refugees and safeguarding their mental health: lessons learned from the Canadian refugee resettlement project. Transcult Psychiatr. 2009;46(4):539-83. https://doi.org/10.1177/1363461509351373.

10. Habib RR, Basma SH, Yeretzian JS. Harboring illnesses: on the association between disease and living conditions in a Palestinian refugee camp in Lebanon. Int J Environ Health Res. 2006;16(2):99-111. https://doi.org/10.1 080/09603120500538341

11. Crea TM, Clavo R, Loughry M. Refugee health and wellbeing: differences between urban and camp-based environments in sub-Saharan Africa. J Refug Stud. 2015;28(3):319-30. https://doi.org/10.1093/jrs/fev003.

12. Reed RV, Fazel M, Jones $L$, Panter-Brick C, Stein A. Mental health of displaced and refugee children resettled in low-income and middle-income countries: risk and protective factors. Lancet. 2012;379(9812):250-65. https:// doi.org/10.1016/S0140-6736(11)60050-0.

13. Porter M, Haslam N. Predisplacement and postdisplacement factors associated with mental health of refugees and internally displaced persons: a metaanalysis. JAMA. 2005:294(5):602-12. https://doi.org/10.1001/jama.294.5.602.

14. Mels C, Derluyn I, Broekaert E, Rosseel Y. The psychological impact of forced displacement and related risk factors on eastern Congolese adolescents affected by war. J Child Psychol Psychiatry. 2010;51(10):1096-104. https:// doi.org/10.1111/j.1469-7610.2010.02241.x.

15. Roberts B, Ocaka KF, Browne J, Oyok T, Sondorp E. Factors associated with post-traumatic stress disorder and depression amongst internally displaced persons in northern Uganda. BMC Psychiatr. 2008;8(1):38. https://doi.org/1 0.1186/1471-244X-8-38.

16. Gruebner O, Rapp MA, Adli M, Kluge U, Galea S, Heinz A. Cities and mental health. Dtsch Arztebl Int. 2017;114(8):121-7. https://doi.org/10.3238/arztebl.2 017.0121

17. Beard JR, Cerdá M, Blaney S, Ahern J, Vlahov D, Galea S. Neighborhood characteristics and change in depressive symptoms among older residents of New York City. Am J Public Health. 2009;99(7):1308-14. https://doi.org/1 0.2105/AJPH.2007.125104.

18. Astell-Burt T, Feng $X$. Association of urban green space with mental health and general health among adults in Australia. JAMA Netw Open. 2019;2(7): e198209. https://doi.org/10.1001/jamanetworkopen.2019.8209.

19. Pham PN, Weinstein HM, Longman T. Trauma and PTSD symptoms in Rwanda: implications for attitudes toward justice and reconciliation. JAMA. 2004;292(5):602-12. https://doi.org/10.1001/jama.292.5.602. 
20. Vinck P, Pham PN, Stover E, Weinstein HM. Exposure to war crimes and implications for peace building in northern Uganda. JAMA. 2007;298(5):54354. https://doi.org/10.1001/jama.298.5.543.

21. UN human rights panel concludes. ISIL is committing genocide against Yazidis [press release]. United Nations: UN News; 2016.

22. Peyre-Costa T, Jenssen T. Close to 200,000 Yazidis remain displaced. Norweigan Refugee Council 2018.

23. Ibrahim H, Ertt V, Catani C, Ismail AA, Neuner F. Trauma and perceived social rejection among Yazidi women and girls who sunvived enslavement and genocide. BMC Med. 2018;16(1):154. https://doi.org/10.1186/s12916-018-1140-5.

24. Iraq. United Nations Office for the Coordination of Humanitarian Affairs; 2019

25. Iraq Mission Displacement Tracking Matrix. International Organization for Migration; 2019.

26. The Humanitarian Crisis in Iraq: Internal Displacement. Enabling Peace in Iraq Center; 2015

27. Iraq: Humanitarian Needs Overview 2019. UN Office for the Coordination of Humanitarian Affairs; 2018.

28. Beyani C. Under the radar: internally displaced persons in non-camp settings. Brookings-LSE Project on Internal Displacement. The Brookings Institution; 2013.

29. Mixed Migration Platform: IDP Perceptions in Northern Iraq. Ground Truth Solutions; 2017.

30. Vulnerability Assessment for Syrian Refugees in Lebanon. UNICEF, UNHCR, WFP; 2017.

31. Creamer M, Bell R, Failla S. Psychometric properties of the impact of event scale - revised. Behav Res Ther. 2003:41(12):1489-96. https://doi.org/10.1016/ j.brat.2003.07.010.

32. Weiss DS, Marmar CR. <h1_ngcontent-c18="'" class="m-t-0" > The Impact of Event Scale-Revised. Assessing Psychol Trauma PTSD. 1997:399-411.

33. Maas J, Verheij RA, de Vries S, Spreeuwenberg P, Schellevis FG,

Groenewegen PP. Morbidity is related to a green living environment. Epidemiol Community Health. 2009;63(12):967-73. https://doi.org/10.1136/ jech.2008.079038.

34. Alcock I, White MP, Wheeler BW, Fleming LE, Depledge MH. Longitudinal effects on mental health of moving to greener and less green urban areas. Environ Sci Technol. 2014;48(2):1247-55. https://doi.org/10.1021/es403688w.

35. Internally displaced persons outside camps: achieving a more equitable humanitarian response. UNHCR; 2010.

36. di Tomasso L. Approaches to Counselling Resettled Refugee and Asylum Seeker Survivors of Organized Violence. International Journal of Child, Youth, \& Family Studies. 2010;1(3/4)

\section{Publisher's Note}

Springer Nature remains neutral with regard to jurisdictional claims in published maps and institutional affiliations.

Ready to submit your research? Choose BMC and benefit from:

- fast, convenient online submission

- thorough peer review by experienced researchers in your field

- rapid publication on acceptance

- support for research data, including large and complex data types

- gold Open Access which fosters wider collaboration and increased citations

- maximum visibility for your research: over $100 \mathrm{M}$ website views per year

At $\mathrm{BMC}$, research is always in progress.

Learn more biomedcentral.com/submissions 